\title{
PENGARUH GENDER CHIEF EXECUTIVE OFFICER (CEO), FINANCIAL EXPERTISE CEO, GENDER KOMITE AUDIT, FINANCIAL EXPERTISE KOMITE AUDIT DAN UKURAN KOMITE AUDIT TERHADAP AUDIT DELAY PADA PERUSAHAAN MANUFAKTUR YANG TERDAFTAR DI BEI PERIODE 2015-2017
}

\author{
Nurlisa Afriliana ${ }^{1}$, Nita Erika Ariani ${ }^{* 2}$ \\ ${ }^{1,2}$ Program Studi Akuntansi Fakultas Ekonomi dan Bisnis Universitas Syiah Kuala \\ e-mail: afriliananurlisa@gmail.com ${ }^{1}$, nea@unsyiah.ac.id ${ }^{2}$
}

\section{* Corresponding Author}

\begin{abstract}
Abstrak
This research examines the impact of chief executive officer (CEO) gender, CEO financial expertise, audit committee gender, audit committee financial expertise, and audit committee size on audit delay. The population in this research are the manufacturing companies listed in Indonesia Stock Exchange for period of 2015-2017. The samples in this research study using purposive sampling method, which the number of observations are 39 studies. The technique of data analysis is using multiple linear regression analysis. The result of this research show that CEO gender, CEO financial expertise, audit committee gender, audit committee financial expertise, and audit committee size have affect on audit delay. Partially the research show that (1) CEO gender has an effect on audit delay, (2) the CEO's financial expertise has an effect on the audit delay, (3) the gender audit committee has no effect on audit delay, (4) the financial expertise of the audit committee has no effect on the audit delay, (5) the size of the audit committee influences audit delay.
\end{abstract}

Keywords: Audit Delay, Chief Executive Officer (CEO) Gender, CEO Financial Expertise, Audit Committee Gender, Audit Committee Financial Expertise, and Audit Committee Size.

\section{Pendahuluan}

Kewajiban perusahaan untuk menerbitkan laporan keuangan yang sudah di audit, terlah diatur dalam Peraturan Otoritas Jasa Keuangan (POJK) Nomor 29 Tahun 2016 yang berhubungan dengan Laporan Tahunan Emiten atau Perusahaan Publik yang menyatakan bahwa OJK harus menerima informasi mengenai laporan tahunan perusahaan paling telat 120 hari setelah tahun buku berakhir. Informasi tersebut juga wajib memenuhi karakteristik yang telah disebutkan dalam Pernyataan Standar Akuntansi Keuangan (2014) No.1 yaitu dapat dipahami, relevan, andal, serta dapat dibandingkan.

Adapun hambatan perusahaan dalam menerbitkan laporan keuangan kepada masyarakat umum yaitu jangka waktu audit yang dilakukan oleh akuntan publik dalam menyelesaikan laporan auditnya. Jangka waktu audit tersebut merupakan salah satu ukuran ketepatan waktu dalam menyampaikan laporan keuangan. Laporan keuangan yang tidak disajikan dengan tepat waktu dapat mengurangi manfaat dari laporan keuangan itu sendiri. Praktik audit yang sesuai dengan standar membuat waktu audit menjadi lebih lama.

Lamanya proses yang diperlukan dalam mengaudit laporan keuangan disebut dengan audit delay atau audit report lag. Definisi dari audit delay adalah perbedaan durasi dalam menyelesaikan laporan audit, terhitung dari tanggal laporan keuangan hingga tanggal laporan audit dipublikasikan (Diastiningsih \& Tenaya, 2017). Jika audit delay lebih lama dari waktu yang telah ditentukan oleh peraturan OJK maka akan menyebabkan penyampaian informasi laporan keuangan menjadi terlambat. Supadmi dan Sari (2014) mengatakan bahwa keterlambatan audit disebabkan oleh lamanya proses audit, yang mempengaruhi ketepatan waktu pelaporan keuangan, sehingga keterlambatan audit merupakan masalah yang sangat penting bagi perusahaan. Semakin lama audit delay akan menggambarkan kurangnya transparansi 
manajemen perusahaan sehingga proses audit tidak berjalan dengan baik dan dapat memperburuk citra perusahaan di mata investor.

Berdasarkan informasi yang diperoleh dari situs liputan6.com (2017), Bursa Efek Indonesia (BEI) melaporkan, hingga 29 Juni 2017 ada 17 perusahaan belum sampaikan laporan keuangan auditan per 31 Desember 2016 dan belum membayar denda atas keterlambatan tersebut. Terkait dengan hal tersebut BEI memberlakukan penghentian sementara perdagangan Efek pada Pasar Regulasi dan Pasar Tunai sejak 30 Juni 2016 untuk 8 perusahaan, serta memperpanjang suspensi perdagangan Efek untuk 9 perusahaan.

Penelitian ini akan membahas mengenai faktor gender dan financial expertise dari Chief Executive Officer (CEO) dan Komite Audit. CEO dan Komite Audit merupakan dua bagian yang berperan penting dalam perusahaan. CEO memiliki peran sebagai seorang pemimpin, dalam pengambil keputusan serta pengelola perusahaan. Komite audit berperan aktif untuk memastikan laporan keuangan telah disajikan sesuai dengan keadaan keuangan perusahaan yang sesungguhnya, perusahaan sudah berjalan sesuai dengan peraturan yang ditetapkan, perusahaan telah beroperasi secara efektif dan sistem pengendalian internal perusahaan telah berjalan dengan baik.

Beberapa penelitian sebelumnya menunjukkan bahwa audit delay dipengaruhi oleh gender CEO (Harjoto, et al., 2015), financial expertise CEO (Harjoto et al., 2015; Baatwah, et al., 2015), gender komite audit (Sari \& Supadmi, 2014; Rianti \& Sari, 2014; Anugrah \& Laksito, 2017; Harjoto, et al., 2015), keahlian/ financial expertise komite audit (Rianti \& Sari, 2014; Anugrah \& Laksito, 2017; Harjoto, et al., 2015; Abernathy, et al., 2014), dan keanggotaan/ ukuran komite audit (Rianti \& Sari, 2014; Anugrah \& Laksito, 2017; Santiani \& Muliartha, 2018). Penelitian ini kembali menguji pengaruh gender CEO, financial expertise CEO, gender komite audit, financial expertise komite audit dan ukuran komite audit terhadap audit delay.

Faktor pertama yang memengaruhi audit delay berdasarkan studi terdahulu adalah gender CEO. Menurut Harjoto, et al. (2015) cara seseorang dalam mengambil keputusan cenderung dipengaruhi oleh perbedaan gender. Biasanya tipe seseorang yang tidak mengambil keputusan (risk averse) dan kurang percaya diri dalam pengambilan keputusan didominasi oleh gender perempuan. CEO perempuan lebih peka terhadap tuntutan yang didapatkan dari investor dan pasar modal untuk menghindari audit delay yang berkepanjangan sehingga dengan memiliki CEO perempuan dapat meningkatkan kemungkinan bahwa perusahaan akan mengeluarkan laporan keuangan yang lebih handal dan tepat waktu. Harjoto et al. (2015) mengungkapkan gender CEO memiliki pengaruh yang signifikan terhadap audit delay.

Faktor lain yang dapat memengaruhi audit delay yaitu financial expertise CEO yaitu kemampuan dalam bidang keuangan yang dimiliki oleh seorang pemimpin perusahaan. Financial expertise yang dimiliki CEO berkaitan dengan latar belakang pendidikan di bidang akuntansi maupun keuangan atau berpangalaman dalam bidangnya (Anggraini, 2017). CEO dengan financial expertise dapat menurunkan tingkat kegagalan dalam hal perkiraan dan penilaian, mengatasi permasalahan rumit, serta memudahkan auditor eksternal dalam melakukan diskusi dan negosiasi terkait permasalahan akuntansi pada laporan keuangan (Baatwah, et al., 2015). Hasil penelitian yang dilakukan oleh Baatwah, et al.(2015) menyimpulkan bahwa financial expertise CEO berpengaruh signifikan terhadap audit delay. Berbeda dengan penelitian yang dilakukan oleh Anggraini (2017) yang menyatakan bahwa financial expertise CEO tidak berpengaruh terhadap audit delay.

Faktor selanjutnya yang dapat memengaruhi audit delay yaitu gender komite audit. Gender adalah perbedaan antara perempuan dan laki-laki dalam hal karakter, prilaku, sikap, dan karakteristik emosional. Gender komite audit diukur menggunakan perbandingan anggota komite audit yang berjenis kelamin perempuan dalam perusahaan. Penelitian yang dilakukan Sari \& Supadmi (2014); Rianti \& Sari (2014); Anugrah \& Laksito (2017); Harjoto et al. (2015) menunjukkan bahwa gender komite audit berpengaruh negatif terhadap audit delay. Hasil yang berbeda ditunjukkan oleh penelitian Santiani dan Muliartha (2018), dimana gender komite audit tidak memiliki pengaruh pada audit delay.

Faktor berikutnya adalah financial expertise komite audit yaitu keahlian yang diperoleh dari pendidikan. Anggota komite audit yang memiliki financial expertise dapat mempermudah fungsi dan peran dari komite audit sehingga proses audit dari 
auditor independen dapat berjalan lebih cepat (Santiani \& Muliartha, 2018). Terdapat hasil penelitian yang kontradiktif mengenai pengaruh financial expertise komite audit pada audit delay. Penelitian yang dilakukan oleh Anugrah \& Laksito (2017); Rianti \& Sari (2014); Sari \& Supadmi (2014); Abernathy et al. (2014) menyimpulkan bahwa financial expertise komite berpengaruh negatif terhadap audit delay. Hasil penelitian ini bertolak belakang dengan penelitian yang dilakukan oleh Santiani \& Muliartha (2018), yang menunjukkan bahwa financial expertise komite tidak berpengaruh terhadap audit delay.

Ukuran komite audit dalam penelitian ini menjadi faktor terakhir yang memengaruhi audit delay. Anggota komite audit harus memiliki jumlah yang cukup dalam melakanakan tugasnya. Semakin banyak anggota komite audit yang dimiliki perusahaan, akan semakin meningkatkan kualitas pengawasan dan membantu komite audit menyelesaikan masalah yang dapat merugikan pemilik, sehingga komite audit dapat mendorong manajemen untuk mengeluarkan laporan keuangan yang tepat waktu (Mohamad-Nor, et al., 2010). Hasil riset Anugrah \& Laksito (2017); Santiani \& Muliartha (2018); dan Rianti \& Sari (2014) mengungkapkan bahwa ukuran komite audit berdampak negatif pada audit delay, sementara Mahendra \& Widhiyani (2017) menunjukkan bahwa ukuran komite audit memiliki pengaruh positif pada audit delay.

Berdasarkan latar belakang yang telah diuraikan, dilakukan penelitian dengan judul "Pengaruh Gender Chief Executive Officer (CEO), Financial Expertise CEO, Gender Komite Audit, Financial Expertise Komite Audit dan Ukuran Komite Audit terhadap Audit Delay pada Perusahaan Manufaktur yang Terdaftar di BEI Periode 2015-2017"'. Perusahaan manufaktur dipilih karena perusahaan manufaktur adalah perusahaan yang mengelola bahan mentah menjadi barang jadi sehingga aktivitas dalam perusahaan manufaktur cukup kompleks. Dengan demikian, hal seperti ini dapat menyebabkan proses audit laporan keuangan perusahaan menjadi lebih rumit dan lebih lama.

\section{Kajian Pustaka dan Pengembangan Hipotesis Teori Keagenan}

Teori keagenan adalah teori yang menjelaskan keterikatan antara pihak manajer dengan pemilik
(Dewi, 2014). Manajer atau agen adalah pihak yang mengatur perusahaan, sedangkan pemilik atau prinsipal adalah pihak yang memiliki modal (pemegang saham), keduanya terkait dalam sebuah kontrak. Menurut Permatasari (2012), agen termotivasi mengadakan kontrak untuk memaksimalkan pemenuhan kebutuhan ekonomi dan psikologisnya, sedangkan prinsipal termotivasi untuk mensejahterakan dirinya dengan profitabilitas yang selalu meningkat.

Dalam praktiknya, terjadi perbedaan kepentingan antara agen dan prisipal. Perbedaan kepentingan ini dapat menyebabkan terjadinya suatu konflik yang disebut agency problems. Agency problems dapat disebabkan oleh ketidaksesuaian informasi (asimetris informasi) antara prinsipal dan agen. Informasi yang tidak seimbang antara agen dan prinsipal dapat memicu terjadinya penyalahgunaan kewajiban oleh agen dalam menyampaikan informasi kepada prinsipal, yaitu dengan menahan informasi yang diminta oleh prinsipal atau memberikan informasi yang tidak sesuai demi keuntungan pribadi agen (Putri, 2014). Dalam hal ini, pihak ketiga sangatlah dibutuhkan untuk menangani permasalahan antara prinsipal dan agen. Pihak ketiga yang dimaksudkan disini yaitu auditor eksternal (akuntan publik) yang dapat memberikan informasi yang berimbang kepada prinsipal. Akuntan publik akan membuat laporan keuangan menjadi lebih andal dan terpercaya sehingga dapat digunakan oleh prinsipal dalam pengambilan keputusan.

Akuntan publik juga berperan penting dalam mengurangi asimetris informasi antara agen dan prinsipal, yaitu dengan mengurangi audit delay sehingga laporan keuangan dapat dipublikasikan secara tepat waktu. Jika auditor membutuhkan waktu yang lama untuk menyelesaikan audit maka audit delay akan menjadi panjang dan publikasi laporan keuangan menjadi terlambat. Hal ini akan menyebabkan asimetris informasi antara prinsipal dan agen akan menjadi semakin besar karena informasi yang dibutuhkan oleh prinsipal tidak tersedia ketika pengambilan keputusan.

\section{Teori Sinyal}

Teori sinyal menyatakan bahwa keputusan investasi yang dilakukan oleh pihak luar perusahaan dipengaruhi oleh informasi penting yang dikeluarkan 
oleh perusahaan (Permatasari, 2012). Perusahaan dengan kinerja yang baik akan memberikan sinyal kepada pasar dengan sengaja agar pasar dapat memprediksi kondisi perusahaan tersebut. Sinyal yang diberikan terkandung dalam informasi yang dipublikasikan oleh perusahaan yang berguna dalam pengambilan keputusan (Hartono, 2005).

Menurut Ayushabrina (2014), pasar akan langsung merespon informasi yang diberikan oleh perusahaan sebagai sinyal kabar baik atau kabar buruk. Investor dapat memutuskan untuk berinvestasi pada suatu perusahaan setelah melihat ketepatan waktu pelaporan keuangan dari setiap perusahaan. Perusahaan yang terlambat mempublikasikan laporan keuangannya berarti mengalami audit delay yang panjang sehingga akan memberikan sinyal yang buruk bagi investor maupun calon investor. Hal ini dikarenakan informasi yang ada kehilangan sifat relevannya dan menjadi tidak berguna dalam proses pengambilan keputusan karena keterlambatan publikasinya. Laporan keuangan yang tidak dipublikasikan secara tepat waktu yang disebabkan oleh panjangnya durasi audit delay akan memberikan sinyal buruk kepada pasar mengenai kondisi perusahaan.

\section{Ketepatan Waktu Laporan Keuangan}

Salah satu dimensi yang paling diperhatikan oleh pemakai laporan keuangan, yaitu ketepatan waktu dalam penyampaian laporan keuangan. Ketepatan waktu laporan keuangan dapat memengaruhi kualitas dan relevansi laporan keuangan itu sendiri. Laporan keuangan yang tidak dipublikasikan secara tepat waktu akan mengakibatkan nilai dari informasi yang ada pada laporan tersebut berkurang, sehingga laporan keuangan menjadi tidak relevan karena tidak tersediannya informasi ketika dibutuhkan dalam pengambilan keputusan.

Kewajiban penyampaian laporan keuangan tahunan diatur dalam peraturan OJK Nomor 29 Tahun 2016 yang menyebutkan bahwa laporan keuangan tahunan wajib disampaikan paling telat 120 hari setelah tahun buku berakhir. OJK juga memiliki wewenang untuk memberikan sanksi administratif terhadap setiap pihak yang melanggar ketentuan tersebut, sanksi-sanksi itu dapat berupa himbauan tertulis, denda berupa sejumlah uang tertentu, pembatasan aktivitas usaha, pembekuan aktivitas usaha, pencabutan izin usaha, pembatalan persetujuan, dan pembatalan pendaftaran.

\section{Audit Delay}

Audit merupakan kegiatan mengevaluasi suatu organisasi, sistem, proses, atau produk. Tujuan dari audit yaitu untuk membuktikan bahwa subjek dari audit telah sesuai dengan kriteria yang telah ditetapkan sebelumnya. Audit atas laporan keuangan akan dilakukan oleh akuntan publik yang tujuannya untuk menilai seberapa wajar atau seberapa layak penyajian laporan keuangan tersebut dibuat oleh perusahaan sesuai dengan prinsip-prinsip yang berlaku umum. Menurut Tuanakotta (2015:3), audit adalah jasa akuntan publik yang dikenal sebagai jasa asurans (assurance servicess).

Durasi yang dibutuhkan auditor eksternal dalam menyelesaikan audit disebut dengan audit delay. Durasi tersebut diukur dari tanggal penutupan tahun buku hingga tanggal penerbitan laporan audit independen (Kartika, 2011). Menurut Sari dan Supadmi (2014), audit delay merupakan jangka waktu yang diperlukan dalam menyelesaikan proses audit, terhitung dari tanggal penerbitan laporan keuangan hingga penerbitan laporan keuangan yang telah di audit. Perusahaan yang terlambat menyampaikan laporan keuangan akan memberikan citra yang buruk bagi perusahaannya di mata para investor dan dapat menyebabkan pengambilan keputusan menjadi tidak pasti.

\section{Gender Chief Executive Officer (CEO)}

Gender Chief Executive Officer (CEO) merupakan salah satu faktor yang dapat mempengaruhi sikap kerja antara CEO perempuan dan CEO laki-laki dalam pengambilan keputusan. Gender CEO dalam penelitian ini menggunakan proporsi perempuan. Menurut Faccio, et al. (2016), perusahaan yang dijalankan oleh CEO perempuan akan mengambil risiko lebih rendah daripada CEO laki-laki. Perempuan lebih konservatif dalam hal strategi pelaporan keuangan. Hal ini tentunya akan memengaruhi laba yang dihasilkan perusahaan menurun yang diakibatkan oleh akrual diskrisioner (Peni \& Vähämaa, 2010). Akrual diskrisioner adalah akrual yang dipengaruhi oleh kebijakan manajeman dalam pengambilan keputusan. 


\section{Financial Expertise CEO}

Financial Expertise CEO merupakan latar belakang pendidikan seorang pemimpin atau direksi di bidang keuangan. CEO dengan financial expertise dapat menurunkan tingkat kegagalan dalam hal perkiraan dan penilaian, mengatasi permasalahan rumit, serta memudahkan auditor eksternal dalam melakukan diskusi dan negosiasi terkait permasalahan akuntansi pada laporan keuangan (Baatwah, et al., 2015). Manurut Mastunaga dan Yeung (2008), CEO yang memiliki financial expertise akan membuat informasi laporan keuangan lebih berkualitas. Hal ini ditinjau dari pelaporan dan pengungkapan laporan keuangan sehingga para pengguna laporan tersebut terutama investor akan tertarik untuk berinvestasi.

\section{Gender Komite Audit}

Gender komite audit dalam penelitian ini dilihat dari jumlah anggota komite audit perempuan dalam perusahaan. Menurut Rianti dan Sari (2014), tingkat ketelitian yang lebih tinggi cenderung dimiliki oleh anggota komite audit perempuan dalam menganalisis laporan keuangan dan hal ini dapat berpengaruh terhadap kualitas laporan keuangan sehingga proses audit dapat terselesaikan dengan cepat. Harjoto, et al. (2015) mengatakan bahwa perempuan bersifat risk everse sehingga komite audit perempuan memiliki tingkat intensitas monitoring yang lebih tinggi dibandingkan dengan komite audit laki-laki untuk menghindari risiko audit delay yang berkepanjangan.

\section{Financial Expertise Komite Audit}

Financial expertise komite audit adalah anggota komite audit yang memiliki kompetensi dalam bidang keuangan. Kompetensi tersebut berkaitan dengan pengalaman dan keahlian dalam melakukan internal control yang baik terhadap manajemen dan menjamin kualitas pelaporan keuangan (Anugrah \& Laksito, 2017). Financial expertise komite audit juga membuat fungsi serta peran dari komite audit lebih berjalan dengan efektif dan dapat mempercepat proses audit dari akuntan publik (Santiani \& Muliartha, 2018).

\section{Ukuran Komite Audit}

Komite audit menurut peraturan OJK Nomor 55 Tahun 2015 adalah komite yang dibuat untuk bertanggungjawab dan membantu dewan komisaris dalam hal pelaksanaan tugas serta fungsi dewan komisaris. Komite audit dalam perusahaan wajib berperan secara independen dalam pelaksanaan tugas dan tanggungjawabnya.

Ukuran komite audit dilihat dari berapa jumlah anggota komite audit yang dimiliki oleh suatu perusahaan. Setidaknya komite audit pada sebuah perusahaan minimal tiga orang, yang berasal dari komisaris independen dan dari pihak luar perusahaan. OJK juga mensyaratkan sekurang-kurangnya ada satu orang anggota komite audit berlatar belakang pendidikan di bidang akuntansi dan keuangan, atau berpengalaman pada bidang tersebut. Menurut Mohammad-Nor, et al. (2010), komite audit yang lebih banyak akan cenderung lebih cepat menemukan dan menyelesaikan permasalahan dalam proses pelaporan keuangan.

\section{Hipotesis}

Berdasarkan kajian pustaka maka, hipotesis dalam penelitian ini adalah:

$\mathrm{H}_{1}$ : Gender chief executive officer (CEO), financial expertise CEO, gender komite audit, financial expertise komite audit, dan ukuran komite audit secara bersama-sama berpengaruh terhadap audit delay.

$\mathrm{H}_{2}$ : Gender CEO berpengaruh terhadap audit delay.

$\mathrm{H}_{3}$ : Financial expertise CEO berpengaruh terhadap audit delay.

$\mathrm{H}_{4}$ : Gender komite audit berpengaruh terhadap audit delay.

$\mathrm{H}_{5}$ : Financial expertise komite audit berpengaruh terhadap audit delay.

$\mathrm{H}_{6}$ : Ukuran komite audit berpengaruh terhadap terhadap audit delay.

\section{Metode Penelitian \\ Desain Penelitian}

Penelitin ini mempunyai tujuan studi yaitu mencari tahu sifat dan hubungan antara variabel bebas dan variabel terikat dalam suatu pengujian hipotesis (hypothesis testing research). Dengan menggunakan tingkat intervensi minimal, disebabkan peneliti hanya mengumpulkan data laporan keuangan perusahaan. Unit analisis yang digunakan dalam penelitian ini adalah tingkat organisasi, yaitu perusahaan manufaktur yang terdaftar di BEI. Data yang dikumpulkan berupa laporan keuangan seluruh perusahaan manufaktur di Indonesia dari tahun 2015-2017. Horizon waktu dalam 
penelitian ini adalah pooled/panel data dimana studi ini merupakan studi yang membutuhkan lebih dari satu tahap pengumpulan data pada waktu yang berbeda.

\section{Populasi dan Sampel Penelitian}

Populasi adalah sekumpulan objek yang memiliki keunggulan dan karakteristik tertentu untuk ditarik kesimpulan serta dikaji lebih dalam oleh peneliti (Sekaran \& Bougie, 2013:240). Bagian terkecil dari populasi disebut sebagai sampel. Seluruh perusahaan manufaktur yang terdaftar secara berturut-turut di BEI pada tahun 2015-2017 merupakan populasi dalam penelitian. Pengambilan sampel memakai metode purposive sampling, yaitu sampel yang memiliki kriteria-kriteria tertentu.

Penentuan Sampel Penelitian

\begin{tabular}{|c|l|c|}
\hline No. & \multicolumn{1}{|c|}{ Kriteria Sampel } & $\begin{array}{c}\text { Jumlah } \\
\text { Perusahaan }\end{array}$ \\
\hline $\mathbf{1 .}$ & $\begin{array}{l}\text { Perusahaan manufaktur yang terdaftar di BEI tahun } \\
2015-2017\end{array}$ & 145 \\
\hline $\mathbf{2 .}$ & $\begin{array}{l}\text { Perusahaan manufaktur yang tidak menerbitkan laporan } \\
\text { keuangan secara berturut-turut periode 2015-2017. }\end{array}$ & $(27)$ \\
\hline $\mathbf{3 .}$ & $\begin{array}{l}\text { Perusahaan manufaktur yang tidak memiliki anggota } \\
\text { komite audit perempuan. }\end{array}$ & $(79)$ \\
\hline \multicolumn{2}{|l|}{ Total Sampel Digunakan } & 39 \\
\hline Jumlah Data Observasi (3 tahun) & 117 \\
\hline
\end{tabular}

Sumber : Data diolah (2018)

\section{Sumber dan Teknik Pengambilan Data}

Sumber data pada studi ini adalah data sekunder yang berupa laporan keuangan perusahaan manufaktur. Data sekunder merupakan data yang mengarah pada informasi yang didapatkan oleh peneliti melalui media perantara (Sekaran dan Bougie (2013:162). Untuk memperoleh data, peneliti mengakses Bursa Efek Indonesia (www.idx.co.id), serta peneliti juga mengumpulkan data yang berhubungan dengan penelitian melalui studi kepustakaan yang berkaitan dengan audit delay.

\section{Operasionalisasi Variabel}

\section{Gender Chief Executive Officer (CEO)}

Gender Chief Executive Officer (CEO) merupakan konsep untuk membedakan antara CEO perempuan dan laki-laki secara individu serta sosialbudaya (Sari \& Supadmi, 2014). Variabel gender CEO ini diukur dengan menggunakan pengukuran yang dilakukan oleh Anggraini (2017), yaitu dengan variabel dummy. Nilai 1 untuk menyatakan gender perempuan dan nilai 0 untuk menyatakan gender lakilaki.

\section{Financial Expertise CEO}

Financial Expertise CEO adalah ilmu yang didapatkan dari pendidikan maupun pekerjaan yang berhubungan dalam bidang akuntansi dan manajemen keuangan (Baatwah, et al., 2015). Pengukuran variabel ini yaitu menggunakan variabel dummy, dengan nilai 1 menyatakan financial expert dan nilai 0 menyatakan non-financial expert (Anggraini, 2017).

\section{Gender Komite Audit}

Gender komite audit merupakan suatu konsep untuk membedakan jenis kelamin komite audit lakilaki dan perempuan secara biologis serta sosial-budaya (Sari \& Supadmi, 2014). Untuk mengukur variabel ini, maka dilakukan perbandingan antara jumlah anggota komite audit perempuan dengan jumlah keseluruhan anggota komite audit. Dengan rumus sebagai berikut:

$$
\text { GKA }=\frac{\text { Anggota komite audit perempuan }}{\text { Jumlah anggota komite audit }} \times 100 \%
$$

\section{Financial Expertise Komite Audit}

Financial expertise komite audit yaitu ilmu yang didapatkan oleh anggota komite audit melalui pendidikan atau berpengalaman bekerja dalam bidang akuntansi (Abernathy, et al., 2014). Variabel ini diukur dengan membandingkan antara jumlah anggota komite audit yang financial expertise dengan jumlah keseluruhan anggota komite audit, secara ringkas dirumuskan sebagai berikut:

$$
\mathrm{FEKA}=\frac{\text { Jumlah anggota komite audit yang financial expertise }}{\text { Jumlah seluruh anggota komite audit }} \times 100 \%
$$

\section{Ukuran Komite Audit}

Menurut DeZoort, et al. (2002) anggota komite audit yang kompeten akan membuat komite audit semakain efektif. Jumlah komite audit dalam suatu perusahaan harus memiliki jumlah yang tercukupi. Hal ini akan membuat komite audit dengan mudah menyelesaikan permasalahan yang dapat merugikan prinsipal sehingga dapat mendorong manajer dalam mempublikasikan laporan keuangan secara tepat waktu. Ukuran komite audit dalam penelitian ini diukur dengan mengikuti pengukuran yang dilakukan oleh penelitian Anugrah dan Laksito (2017), yaitu dengan menghitung total jumlah komite audit yang dimiliki oleh perusahaan. 


\section{Hasil dan Pembahasan \\ Hasil Penelitian \\ Deskripsi Objek Penelitian}

Tujuan dari studi ini yaitu menguji pengaruh gender chief executive officer (CEO), financial expertise CEO, gender komite audit, financial expertise komite audit, dan ukuran komite audit terhadap audit delay pada perusahaan manufaktur yang terdaftar di BEI periode 2015-2017. Pengambilan sampel memakai metode purposive sampling dengan menetapkan kriteria yang telah ditentukan.

Horizontal waktu yang digunakan adalah pooled data (panel data), dimana studi ini merupakan studi yang memerlukan lebih dari satu tahap pengumpulan data pada waktu yang berbeda. Seluruh perusahaan manufaktur yang terdaftar di BEI periode 2015-2017 adalah populasi pada penelitian ini. Berdasarkan dengan kriteria yang telah ditentukan, terdapat 39 sampel perusahaan manufaktur dengan jumlah data observasi 117 sampel. Metode analisis regresi linear berganda digunakan sebagai metode analisis dalam penelitian ini.

\section{Hasil Pengujian Regresi Linear Berganda Regresi Linear Berganda}

\begin{tabular}{|c|c|c|c|c|c|c|c|c|}
\hline \multirow{2}{*}{\multicolumn{2}{|c|}{ Model }} & \multicolumn{4}{|c|}{ Coefficients $^{\mathrm{a}}$} & \multirow[b]{3}{*}{ Sig. } & & \\
\hline & & \multicolumn{2}{|c|}{$\begin{array}{c}\text { Unstandardized } \\
\text { Coefficients }\end{array}$} & \multirow{2}{*}{$\begin{array}{c}\text { Standardized } \\
\text { Coefficients } \\
\text { Beta }\end{array}$} & \multirow[b]{2}{*}{$i$} & & \multicolumn{2}{|c|}{$\begin{array}{l}\text { Collinearity } \\
\text { Statistics }\end{array}$} \\
\hline & & B & $\begin{array}{l}\text { Std. } \\
\text { Error }\end{array}$ & & & & Tolerance & VIF \\
\hline \multirow[t]{6}{*}{1} & (Constant) & 121.766 & 16.278 & & 7.480 & .000 & & \\
\hline & GCEO & -9.540 & 3.418 & -.238 & -2.791 & .006 & .985 & 1.016 \\
\hline & FECEO & -5.504 & 2.179 & -.228 & -2.527 & .013 & .880 & 1.136 \\
\hline & GKA & -4.489 & 6.241 & -.063 & -.719 & .473 & .932 & 1.073 \\
\hline & FEKA & 2.279 & 4.727 & .044 & .482 & .631 & .866 & 1.155 \\
\hline & UKA & -14.814 & 4.931 & -.262 & -3.005 & .003 & .945 & 1.058 \\
\hline
\end{tabular}

a. Dependent Variable: AD

Sumber: output SPSS (2018)

Sesuai dengan hasil perhitungan statistik yang terlihat pada Tabel 4.11 dapat di rumuskan kedalam persamaan regresi linear berganda sebagai berikut:

\section{$\mathrm{AD}=121,766-9,540 \mathrm{X} 1-5,504 \mathrm{X} 2-4,439 \mathrm{X} 3+2,279 \mathrm{X} 4-14,814 \mathrm{X} 5+\mathrm{e}$}

Berdasarkan formulasi regresi linear berganda di atas dapat disimpulkan bahwa nilai konstanta sebesar 121,766 memiliki arti jika nilai variabel independen sama dengan nol, maka rata-rata waktu penyelesaian audit dari akhir periode sampai dengan tanggal laporan audit dipublikasikan yaitu sebesar 121 hari, dengan asumsi variabel independen dianggap konstan, ini menunjukkan bahwa terjadinya audit delay karena penyelesaian audit lebih dari 120 hari.

Koefisien regresi gender CEO sebesar -9,540 dan bertanda negatif, artinya setiap kenaikan satu persen gender CEO maka akan mengakibatkan penurunan audit delay sebesar 9,540 hari dengan asumsi variabel bebas lainnya konstan. Tanda koefisien regresi gender CEO yang negatif menunjukkan pengaruh tidak searah. Apabila perusahaan memiliki CEO dengan gender perempuan akan menyebabkan semakin pendek waktu yang dibutuhkan dalam penyelesaian audit.

Koefisien regresi financial expertise CEO sebesar -5,504 dan bertanda negatif, artinya setiap kenaikan satu persen financial expertise CEO maka akan mengakibatkan penurunan audit delay sebesar 5,504 hari dengan asumsi variabel bebas lainnya konstan. Tanda koefisien regresi financial expertise CEO yang negatif menunjukkan pengaruh tidak searah. Apabila perusahaan memiliki CEO dengan financial expertise akan menyebabkan semakin pendek waktu yang dibutuhkan dalam penyelesaian audit.

Koefisien regresi gender komite audit sebesar 4,489 dan bertanda negatif, artinya setiap kenaikan satu persen jumlah gender dalam susunan komite audit akan menurunkan audit delay sebanyak 4,489 hari dengan asumsi variabel bebas lainnya konstan. Koefisien regresi gender komite audit yang bertanda negatif menunjukkan pengaruh tidak searah. Semakin banyak gender perempuan dalam komite audit dapat menyebabkan semakin pendek waktu yang dibutuhkan dalam penyelesaian audit.

Koefisien regresi financial expertise komite audit sebesar 2,279 dan bertanda positif, artinya setiap kenaikan satu persen jumlah financial expertise komite audit akan menyebabkan audit delay meningkat sebesar 2,279 hari dengan asumsi variabel bebas lainnya konstan. Tanda koefisien regresi financial expertise komite audit positif menunjukkan pengaruh yang searah. Semakin sedikit proporsi financial expertise dalam susunan komite audit menyebabkan semakin pendek waktu penyelesaian audit yang diperlukan.

Koefisien regresi ukuran komite audit sebesar 14,814 dan bertanda negatif, artinya setiap kenaikan satu persen jumlah ukuran komite audit akan mengakibatkan penurunan audit delay sebesar 14,814 hari dengan asumsi variabel bebas lainnya konstan. 
Tanda koefisien regresi ukuran komite audit negatif menunjukkan pengaruh yang tidak searah. Semakin sedikit proporsi ukuran komite audit menyebabkan semakin panjang waktu penyelesaian audit yang dibutuhkan.

\section{Uji Statistik F}

Uji statistik F dilakukan untuk melihat apakah gender CEO, financial expertise CEO, gender komite audit, financial expertise komite audit, dan ukuran komite audit berpengaruh secara bersama-sama terhadap audit delay.

\begin{tabular}{|c|c|c|c|c|c|c|}
\hline \multicolumn{7}{|c|}{ Hasil Uji Statistik F } \\
\hline \multicolumn{7}{|c|}{ ANOVA $^{a}$} \\
\hline \multicolumn{2}{|c|}{ Model } & $\begin{array}{l}\text { Sum of } \\
\text { Squares }\end{array}$ & $\mathrm{df}$ & $\begin{array}{l}\text { Mean } \\
\text { Square }\end{array}$ & $\mathrm{F}$ & Sig. \\
\hline \multirow[t]{3}{*}{1} & Regression & 3260.297 & 5 & 652.059 & 5.687 & $.000^{\mathrm{b}}$ \\
\hline & Residual & 12726.472 & 111 & 114.653 & & \\
\hline & Total & 15986.769 & 116 & & & \\
\hline
\end{tabular}

a. Dependent Variable: AD

b. Predictors: (Constant), UKA, GKA, GCEO, FECEO, FEKA Sumber: output SPSS (2018)

Sesuai dengan data statistik pada Tabel diatas nilai signifikansi adalah sebesar 0,000 dan < taraf signifikan 0,05 (5\%), maka dapat disimpulkan bahwa hipotesis pertama $\left(\mathrm{H}_{1}\right)$ diterima, sehingga variabel gender CEO, financial expertise CEO, gender komite audit, financial expertise komite audit, dan ukuran komite audit secara bersama-sama berpengaruh terhadap audit delay.

\section{Uji Statistik t}

Pengujian statistik t pada dasarnya dilakukan untuk melihat seberapa jauh pengaruh variabel independen terhadap variabel dependen secara individual. Pengujian ini dilakukan untuk mengetahui seberapa besar pengaruh gender $\mathrm{CEO}$, financial expertise CEO, gender komite audit, financial expertise komite audit, dan ukuran komite audit terhadap audit delay. Keputusan diambil dengan melihat nilai signifikansi kurang dari 0,05 (5\%).

\begin{tabular}{|c|c|c|c|c|c|c|c|c|}
\hline \multicolumn{9}{|c|}{ Coefficients $^{\mathrm{a}}$} \\
\hline \multirow{2}{*}{\multicolumn{2}{|c|}{ Model }} & \multicolumn{2}{|c|}{$\begin{array}{l}\text { Unstandardized } \\
\text { Coefficients }\end{array}$} & \multirow{2}{*}{$\begin{array}{c}\text { Standardized } \\
\text { Coefficients } \\
\text { Beta }\end{array}$} & \multirow[b]{2}{*}{$\tau$} & \multirow[b]{2}{*}{ Sig. } & \multicolumn{2}{|c|}{$\begin{array}{l}\text { Collinearity } \\
\text { Statistics }\end{array}$} \\
\hline & & B & $\begin{array}{l}\text { Std. } \\
\text { Error }\end{array}$ & & & & Tolerance & VIF \\
\hline \multirow[t]{6}{*}{1} & (Constant) & 121.766 & 16.278 & & 7.480 & .000 & & \\
\hline & GCEO & -9.540 & 3.418 & -.238 & -2.791 & .006 & .985 & 1.016 \\
\hline & FECEO & -5.504 & 2.179 & -.228 & -2.527 & .013 & .880 & 1.136 \\
\hline & GKA & -4.489 & 6.241 & -.063 & -.719 & .473 & .932 & 1.073 \\
\hline & FEKA & 2.279 & 4.727 & .044 & .482 & .631 & .866 & 1.155 \\
\hline & UKA & -14.814 & 4.931 & -.262 & -3.005 & .003 & .945 & 1.058 \\
\hline
\end{tabular}

a. Dependent Variable: AD

Sumber: output SPSS (2018)
Pada tabel diatas terlihat bahwa nilai signifikansi variabel gender CEO sebesar 0,006 < 0,05 (5\%). Nilai tersebut menggambarkan bahwa gender CEO dapat memengaruhi audit delay. Dengan demikian, hipotesis kedua $\left(\mathrm{H}_{2}\right)$ diterima.

Nilai signifikansi variabel financial expertise CEO sebesar 0,013 $<0,05(5 \%)$. Hal ini menunjukkan bahwa financial expertise CEO dapat memengaruhi audit delay. Dengan demikian, hipotesis ketiga $\left(\mathrm{H}_{3}\right)$ diterima.

Nilai signifikansi variabel gender komite audit sebesar 0,473 > dari 0,05 (5\%). Hal ini menunjukkan bahwa gender komite audit tidak dapat memengaruhi audit delay. Dengan demikian, hipotesis keempat $\left(\mathrm{H}_{4}\right)$ ditolak.

Nilai signifikansi variabel financial expertise komite audit sebesar 0,631 > dari 0,05 (5\%). Hal ini menunjukkan bahwa financial expertise komite audit tidak dapat memengaruhi audit delay. Dengan demikian, hipotesis kelima $\left(\mathrm{H}_{5}\right)$ ditolak.

Nilai signifikansi variabel ukuran komite audit sebesar $0,003<0,05$ (5\%). Hal ini menunjukkan bahwa ukuran komite audit dapat memengaruhi audit delay. Dengan demikian, hipotesis keenam $\left(\mathrm{H}_{6}\right)$ diterima.

\section{Uji Koefisien Determinasi $\left(\mathbf{R}^{2}\right)$}

Untuk mengukur seberapa besar kemampuan model dalam menjelaskan variasi variabel maka dilakukan uji koefisien determinasi. Nilai dari uji koefisien determinasi harus berada diantara 0 dan 1 .. Hasil Uji Koefisien Determinasi

\begin{tabular}{|l|c|r|r|r|r|}
\hline \multicolumn{7}{|c|}{ Model Summary $^{\mathrm{b}}$} \\
\hline Model & \multicolumn{1}{|c|}{$\mathrm{R}$} & R Square & $\begin{array}{c}\text { Adjusted R } \\
\text { Square }\end{array}$ & $\begin{array}{c}\text { Std. Error of } \\
\text { the Estimate }\end{array}$ & $\begin{array}{c}\text { Durbin- } \\
\text { Watson }\end{array}$ \\
\hline 1 & $.452^{\mathrm{a}}$ & .204 & .168 & 10.70761 & 1.802 \\
\hline
\end{tabular}

a. Predictors: (Constant), UKA, GKA, GCEO, FECEO, FEKA

b. Dependent Variable: AD

Sumber: output SPSS (2018)

Terlihat pada Tabel diatas nilai $\mathrm{R}^{2}$ s 0,204 atau $20,4 \%$. Hal ini menggambarkan bahwa $20,4 \%$ variabel audit delay dapat dijelaskan oleh kelima variabel dalam riset ini yaitu gender $\mathrm{CEO}$, financial expertise CEO, gender komite audit, financial expertise komite audit, dan ukuran komite audit, sedangkan 79,6\% lainnya dijelaskan oleh variabel lainnya. 


\section{Pembahasan Hasil Pengujian Hipotesis}

Pengaruh Gender Chief Executive Officer (CEO), Financial Expertise CEO, Gender Komite Audit, Financial Expertise Komite Audit, dan Ukuran Komite Audit Terhadap Audit Delay.

Berdasarkan hasil pengujian statistik $\mathrm{F}$ yang diperoleh bahwa variabel bebas yaitu gender CEO, financial expertise CEO, gender komite audit, financial expertise komite audit, dan ukuran komite audit secara bersama-sama berpengaruh terhadap audit delay. Diantara kelima variabel bebas tersebut hanya tiga variabel yang berpegaruh siknifikan terhadap audit delay yaitu gender $\mathrm{CEO}$, financial expertise CEO, dan ukuran komite audit sedangkan variabel bebas lainnya yaitu gender komite audit dan financial expertise komite audit tidak berpengaruh secara signifikan terhadap audit delay.

\section{Pengaruh Gender Chief Executive Officer (CEO) Terhadap Audit Delay.}

Hasil penelitian menunjukkan bahwa gender CEO berpengaruh secara negatif terhadap audit delay dan mendukung hipotesis kedua. Artinya perusahaan yang dijalankan oleh CEO perempuan akan membuat audit delay semakin cepat dan perusahaan yang dijalankan oleh CEO laki-laki akan membuat audit delay semakin lama.

\begin{tabular}{|c|l|c|c|c|}
\hline \multicolumn{2}{|c|}{ Statistik Deskriptif per Tahun } \\
\cline { 3 - 5 } \multicolumn{2}{|c|}{} & \multicolumn{3}{|c|}{ Rata-rata Audit Delay per Tahun } \\
\cline { 3 - 5 } \multicolumn{2}{|c|}{} & 2015 & 2016 & 2017 \\
\hline GCEO & Laki-laki & 78 & 74 & 72 \\
& Perempuan & 72 & 64 & 56 \\
\hline
\end{tabular}

Sumber: Data diolah (2018)

Berdasarkan hasil statistik deskriptif pada tabel diatas, terlihat bahwa rata-rata nilai audit delay per tahun untuk gender laki-laki lebih tinggi dibandingkan dengan gender perempuan. Hal ini menunjukkan bahwa perusahaan yang dilanjankan oleh CEO perempuan memungkinkan dapat mengurangi tingkat audit delay. CEO yang mengindari resiko cenderung menciptakan pengendalian internal yang baik dan mempercepat proses audit, sehingga mengurangi tingkat audit delay.

Hasil riset ini konsisten dengan hasil riset yang dilakukan oleh Harjoto, et al. (2015) dan Anggraini (2017) yang menunjukkan bahwa gender CEO memiliki efek negatif pada audit delay. CEO perempuan memengaruhi audit delay karena perempuan cenderung mengambil resiko ketika mengambil keputusan (Harjoto, et al, 2015 dan Faccio, et al, 2016).

\section{Pengaruh Financial Expertise CEO Terhadap Audit Delay.}

Hasil penelitian menunjukkan bahwa financial expertise CEO berpengaruh secara negatif terhadap audit delay dan menerima hipotesis ketiga. Artinya jika CEO perusahaan memiliki latar belakang pendidikan dibidang akuntansi atau keuangan, maka akan membantu mengurangi penundaan audit yang lama.

Seorang CEO yang memiliki financial expertise dapat dengan mudah memahami permasalahan akuntansi dalam laporan keuangan perusahaan sehingga menurunkan tingkat kegagalan dalam hal perkiraan dan penilaian, serta permasalahan tersebut dapat terselesaikan dengan cepat. Kehadiran financial expertise CEO juga akan membuat laporan keuangan lebih berkualitas, hal ini dilihat dari pelaporan dan pengungkapan laporan keuangan yang tepat waktu, sehingga dengan ketepatan waktu penyampaian laporan tersebut memudahkan para inverstor untuk mengakses informasi yang dibutuhkan (Mastunaga dan Yeung, 2008). Hasil penelitian ini selaras dengan hasil penelitian yang dilakukan oleh Baatwah, et al (2015) yang menyatakan bahwa financial expertise CEO berpengaruh signifikan terhadap audit delay.

\section{Pengaruh Gender Komite Audit Terhadap Audit Delay.}

Hasil penelitian menunjukkan bahwa gender komite audit tidak berpengaruh terhadap audit delay dan menolak hipotesis keempat. Artinya gender komite audit yang diukur berdasarkan persentase jumlah anggota komite audit perempuan dengan seluruh jumlah anggota komite audit yang dimiliki perusahaan tidak berpengaruh terhadap audit delay.

Diferensiasi peran antara perempuan dan lakilaki bukan disebabkan oleh adanya perbedaan biologis, melainkan lebih disebabkan karena adanya faktor sosial (Puspitawati, 2010). Peran gender dapat berubah dalam kondisi, waktu, dan tempat yang berbeda sehingga peran perempuan dan laki-laki dapat dipertukarkan. Penelitian ini mendukung penelitian yang dilakukan oleh Santiani \& Muliartha (2018) yang 
menyatakan bahwa gender komite audit tidak berpengaruh terhadap audit delay.

\section{Pengaruh Financial Expertise Komite Audit Terhadap Audit Delay.}

Hasil penelitian menunjukkan bahwa financial expertise komite audit tidak berpengaruh terhadap audit delay dan menolak hipotesis kelima. Artinya komite audit yang diukur dengan persentase jumlah komite audit yang memiliki financial expertise atau berlatar belakang pendidikan dibidang akuntansi dan keuangan terhadap jumlah anggota komite audit tidak mempengaruhi terjadinya audit delay.

Hasil penelitian ini mendukung penelitian yang dilakukan oleh Ningsih \& Widhiyani (2015) dan Santiani \& Muliartha (2018) yang menyatakan bahwa financial expertise komite audit atau keahlian komite audit tidak berpengaruh terhadap audit delay. Komite audit hanya bertugas sebagai pengawas independen sehingga wewenang dalam penerbitan laporan keuangan auditan suatu perusahaan masih sebagian besar tanggungjawab auditor sebagai pengaudit laporan keuangan.

\section{Pengaruh Ukuran Komite Audit Terhadap Audit Delay.}

Hasil riset menunjukkan bahwa ukuran komite audit berpengaruh negatif terhadap audit delay sehingga hipotesis keenam dapat diterima. Artinya semakin banyak jumlah anggota komite audit maka akan semakin mengurangi tingkat audit delay dan sebaliknya, semakin sedikit jumlah anggota komite audit yang dimiliki perusahaan maka audit delay akan semakin panjang.

Salah satu tugas dan tanggung jawab komite audit yaitu melakukan komunikasi dan pengawasan terhadap kinerja auditor sehingga semakin banyak anggota komite audit yang dimiliki perusahaan, akan semakin meningkatkan kualitas pengawasan dan audit delay akan semakin berkurang (Gunarsa \& Putri, 2017). Kemungkinan masalah yang muncul akan cepat ditemukan dan terselesaikan dengan jumlah anggota komite audit yang lebih banyak. Hasil penelitian ini sejalan dengan penelitian yang dilakukan oleh Anugrah \& Laksito (2017), Santiani \& Muliartha (2018), Gunarsa \& Putri (2017), dan Rianti \& Sari (2014) yang menemukan hasil bahwa ukuran komite audit berpengaruh negatif terhadap audit delay.

\section{Kesimpulan, Keterbatasan, dan Saran}

Sesuai dengan hasil pembahasan penelitian yang sudah dijelaskan sebelumnya, dapat ditarik kesimpulan sebagai berikut:

1) Gender CEO, financial expertise CEO, gender komite audit, financial expertise komite audit, dan ukuran komite audit secara bersama-sama berpengaruh terhadap audit delay.

2) Gender CEO berpengaruh terhadap audit delay.

3) Financial expertise CEO berpengaruh terhadap audit delay.

4) Gender komite audit tidak berpengaruh terhadap audit delay.

5) Financial expertise komite audit tidak berpengaruh terhadap audit delay.

6) Ukuran komite audit berpengaruh terhadap audit delay.

Penelitian ini memiliki beberapa kelemahan yang membatasi keunggulannya. Oleh karena itu, keterbatasan ini perlu diperhatikan dalam penelitian selanjutnya. Studi ini hanya meneliti perusahaan manufaktur yang terdaftar di BEI yang memiliki kriteria tertentu yang telah ditetapkan sebelumnya, sehingga hasilnya tidak dapat digeneralisasi untuk seluruh perusahaan yang terdaftar di BEI. Periode penelitian yang digunakan hanya terbatas tiga tahun yang berakibat pada kecilnya jumlah perusahaan yang menjadi sampel pada penelitian. Nilai $R^{2}$ dalam penelitian ini masih sangat rendah, yang berarti masih banyak variabel independen lain yang dapat memengaruhi audit delay yang tidak dimasukkan dalam penelitian ini.

Saran yang ingin peneliti berikan untuk penelitian selanjutnya adalah menggunakan objek dari semua perusahaan yang terdaftar di BEI, bukan hanya perusahaan manufaktur, sehingga ada perbandingan antara perusahaan yang telambat menyajikan laporan keuangan dengan perusahaan yang tidak terlambat menyajikan laporan keuangan, memperpanjang periode studi untuk memberikan hasil yang lebih valid, karena studi ini hanya menggunakan data periode 2015-2017, dan menambah variabel independen lain yang diduga dapat memengaruhi audit delay yang tidak termasuk dalam penelitian ini, seperti audit tenure, indepndensi, reputasi KAP, financial distress, dan kompleksitas operasi 


\section{Daftar Pustaka}

Abbott, L. J., Parker, S., \& Presley, T. J. (2012). Female Board Presence and the Likelihood of Financial Restatement. Accounting Horizons, 26(4), 607-629.

Abernathy, J. L., Beyer, B., Masli, A., \& Stefaniak, C. (2014). The Association Between Characteristics of Audit Committee Accounting Experts, Audit Committee Chairs, and Financial Reporting Timeliness. Advances in Accounting, 30(2), 283297.

Anggraini, L. W. (2017). Pengaruh Gender dan Financial Expertise dari Chief Executive Officer (CEO) dan Komite Audit Terhadap Audit Delay Pada Perusahaan Manufaktur yang Terdaftar di BEI Periode 2013-2015. Skripsi. Surabaya: Universitas Airlangga.

Anugrah, E. Y., \& Laksito, H. (2017). Pengaruh Efektivitas Komite Audit Terhadap Ketetapan Waktu Pelaporan (Studi Empiris pada Perusahaan Non Keuangan Terdaftar di BEI Tahun 2015). Diponegoro Journal of Acccounting, 6(4), 1-13.

Ayushabrina, F. (2014). Pengaruh Faktor Internal Dan Eksternal Perusahaan Terhadap Audit Report Lag (Studi Empiris pada Perusahaan Non-financial yang Terdaftar di Bursa Efek Indonesia Tahun 2012). Skripsi. Semarang: Universitas Diponegoro.

Baatwah, S. R., Salleh, Z., \& Ahmad, N. (2015). CEO Characteristics and Audit Report Timeliness: Do CEO Tenure and Financial Expertise Matter? Managerial Auditing Journal, 30(8/9), 9981022.

Bangun, P., Subagyo, \& Tarigan, M. U. (2012). Faktor-Faktor yang Mempengaruhi Audit Report Lag pada Perusahaan yang Listed di Bursa Efek Indonesia. Jurnal Pekan Ilmiah Dosen FEBUKSW.

Dewi, S. G. P. (2014). Pengaruh Kualitas Audit Dan Tenure audit Terhadap Audit Report Lag Dengan Spesialisasi Auditor Sebagai Variabel Pemoderasi. Skripsi. Semarang: Program Sarjana Universitas Diponegoro

DeZoort, F. T., Hermanson, D. R., Archambeault, D. S., \& Reed, S. A. (2002). Audit Committee Effectiveness: A Synthesis of the Empirical Audit Committee Literature. Journal of Accounting Literature, 21, 38-75.

Diastiningsih, N. putu J., \& Tenaya, G. A. I. (2017). Spesialisasi Auditor sebagai Pemoderasi Pengaruh Audit Tenure dan Ukuran KAP pada Audit Report Lag. E-Jurnal Akuntansi Universitas Udayana, 18(2), 1230-1258.

Dyer, J. C., \& McHugh, A. J. (1975). The Timeliness of the Australian Annual Report. Journal of Accounting Research, 13(2), 204.

Faccio, M., Marchica, M. T., \& Mura, R. (2016). CEO Gender, Corporate Risk-Taking, and the Efficiency of Capital Allocation. Journal of Corporate Finance, 39, 193-209.

Ghozali, I. (2013). Aplikasi Analisis Multivariat Dengan Program IBM SPSS 21 (7th ed.). Semarang: Universitas Diponegoro.

Gunarsa, I. G. A. C., \& Putri, I. A. D. (2017). Pengaruh Komite Audit, Independensi Komite Audit, dan Profitabilitas Terhadap Audit Report Lag di Perusahaan Manufaktur. E-Jurnal Akuntansi Universitas Udayana, 20, 1672-1703.

Harjoto, A. M., Laksmana, I., \& Lee, R. (2015). Article Information:The Impact of Demographic Characteristics of CEOs and Directors on Audit Fees and Audit Delay. European Journal of Marketing, 24(5), 41-49.

Hartono. (2005). Hubungan Teori Signalling Dengan Underpricing Saham Perdana Di Bursa Efek Jakarta. Jurnal Bisnis Dan Manajemen, 5.

IAI. (2014). Standar Akuntansi Keuangan. Jakarta: Salemba Empat.

Jensen, M. C., \& Meckling, W. H. (1976). Theory of The Firm: Managerial Behavior, Agency Costs and Ownership Structure. Journal of Financial Economics, 3(4), 305-360.

Kartika, A. (2011). Faktor-faktor yang Mempengaruhi Audit Delay pada Perusahaan Manufaktur yang Terdaftar di BEI. Dinamika Keuangan Dan Perbankan, 3(2), 152-171.

Kumara, R. A. (2015). Pengaruh Good Corporate Governance Terhadap Audit Report Lag. Skripsi. Semarang: Program Sarjana Universitas Diponegoro.

Liputan6.com. (2016). Belum Sampaikan Laporan Tahunan, BEI Beri Sanksi ke 63 Emiten. Melalui (https://www.liputan6.com). Diakses tanggal 06 April 2018.

Liputan6.com. (2017). Belum Sampaikan Laporan Keuangan, BEI Suspensi 17 Saham Emiten. Melalui (https://www.liputan6.com). Diakses tanggal 06 April 2018.

Mahendra, A. A. N. P., \& Widhiyani, N. L. S. (2017). Pengaruh GCG , Opini Auditor dan Internal Auditor Terhadap Audit Delay pada Perusahaan Telekomunikasi. E-Jurnal Akuntansi Universitas Udayana, 21, 1601-1629

Matsunaga, S. R., \& Yeung, P. E. (2008). Evidence on the Impact of a CEO's Financial Experience on Quality of the Firm's Financial Reports and Disclosures. AAA 2008 Financial Accounting and Reporting Section (FARS) Paper.

Mazkiyani, N., \& Handoyo, S. (2017). Audit report lag 
of listed companies in Indonesia stock exchange. Jurnal Aplikasi Bisnis, 17(1), 77-95.

Mohamad-Nor, M. N., Shafie, R., \& Wan-Hussin, W. N. (2010). Corporate governance and audit report lag. Asian Academy of Management Journal of Accounting and Finance, 6(2), 57-84.

Neraca.co.id. (2015). Payah, 52 Emiten Telat Laporkan Keuangan. Melalui (http://www.neraca.co.id). Diakses tanggal 06 April 2018.

Ningsih, I. G. A. P. S., \& Widhiyani, N. L. S. (2015). Pengaruh Ukuran Perusahaan, Laba Operasi, Solvabilitas, dan Komite Audit Pada Audit Delay. E-Jurnal Akuntansi Universitas Udayana, 12(3), 481-495.

Peni, E., \& Vähämaa, S. (2010). Female executives and earnings management. Managerial Finance, 36(7), 629-645.

Permatasari, V. M. (2012). Pengaruh Profitabilitas, Solvabilitas, Ukuran Perusahaan, Ukuran Kantor Akuntan Publik, dan Opini Auditor. Skripsi. Yogyakarta: Program Sarjana Universitas Sanata Dharma.

POJK. (2015). Peraturan Otoritas Jasa Keuangan Republik Indonesia. Nomor 55 /POJK.04/2015 Tentang Pembentukan Dan Pedoman Pelaksanaan Kerja Komite Audit.

POJK. (2016). Peraturan Otoritas Jasa Keuangan Republik Indonesia. Nomor 29/POJK.04/2016 Tentang Laporan Tahunan Emiten atau Perusahaan Publik.

Puspitawati, H. (2010). Persepsi Peran Gender Terhadap Pekerjaan Domestik Dan Publik Pada Mahasiswa IPB. Jurnal Studi Gender \& Anak, 5(1), 17-34.

Putri, A. N. I. (2014). Faktor-Faktor yang Berpengaruh Terhadap Audit Report Lag pada Perusahaan Manufaktur yang Terdaftar di Bursa Efek Indonesia Periode Tahun 2008-2012. Skripsi. Semarang: Program Sarjana Universitas Diponegoro.

Rianti, N. L. P. A. E., \& Sari, M. M. R. (2014). Karakteristik Komite Audit dan Audit Delay. EJurnal Akuntansi Universitas Udayana, 6(3), 488-508.

Santiani, K. N., \& Muliartha, K. (2018). Pengaruh Independensi, Keanggotaan, Kompetensi, Dan Gender Komite Audit Terhadap Audit Delay Komang. E-Jurnal Akuntansi Universitas Udayana, 23, 436-460.

Sari, M. M. R., \& Supadmi, N. L. (2014). Gender Audit Committee and Audit Delay. The Indonesian Accounting Review, 4(1), 81-88.

Sekaran, U., \& Bougie, R. (2013). Research Methods for Bussiness. United Kingdom: Jhon Wiley \&
Sons ltd.

Thiruvadi, S. (2012). Gender Differences and Audit Committee Diligence. Gender in Management: An International Journal, 27(6), 366-379.

Tuanakotta, T. M. (2015). Audit Kontemporer. Jakarta: Salemba Empat. 